Body Composition Assessment in Children and Adolescents 


\section{Medicine and Sport Science}

\section{Vol. 44}

Series Editors J. Borms, Brussels

M. Hebbelinck, Brussels

L.J. Micheli, Boston, Mass.

KARGER Basel-Freiburg-Paris-London-New York- 


\title{
Body Composition Assessment in Children and Adolescents
}

\author{
Volume Editors $\quad$ T. Jürimäe, Tartu, Estonia \\ A.P. Hills, Brisbane, Australia
}

26 figures and 50 tables, 2001

KARGER Pasel-Freiburg-Paris-London-New York- 


\section{Medicine and Sport Science}

Published on behalf of the International Council of Sport Science and Physical Education Founder and Editor from 1969 to 1984: E. Jokl ${ }^{\dagger}$, Lexington, Ky.

\section{Toivo Jürimäe}

Faculty of Exercise and Sport Sciences

University of Tartu

18. Ülikooli Street

50090 Tartu (Estonia)

\section{Andrew P. Hills}

School of Human Movement Studies Queensland University of Technology Kelvin Grove Campus

Victoria Park Road

Kelvin Grove 4059

Brisbane, QLD (Australia)

Library of Congress Cataloging-in-Publication Data

Body composition assessment in children and adolescents / volume editors, T. Jürimäe A.P. Hills.

p.; cm. - (Medicine and sport science; vol. 44)

Includes bibliographical references and indexes.

ISBN 3805571313 (hard cover : alk. paper)

1. Children - Physiology. 2. Teenagers - Physiology. 3. Body

composition - Measurement. I. Jürimäe, T. II. Hills, Andrew P. III. Series.

[DNLM: 1. Body Composition - Adolescence. 2. Body Composition - Child. 3

Anthropometry - Adolescence. 4. Anthropometry - Child. QU 100 B6675 2001]

RJ125 B63 2001

$612-\mathrm{dc} 21$

Bibliographic Indices. This publication is listed in bibliographic services, including Current Contents ${ }^{\circledR}$ and Index Medicus.

Drug Dosage. The authors and the publisher have exerted every effort to ensure that drug selection and dosage set forth in this text are in accord with current recommendations and practice at the time of publication. However, in view of ongoing research, changes in government regulations, and the constant flow of information relating to drug therapy and drug reactions, the reader is urged to check the package insert for each drug for any change in indications and dosage and for added warnings and precautions. This is particularly important when the recommended agent is a new and/or infrequently employed drug.

All rights reserved. No part of this publication may be translated into other languages, reproduced or utilized in any form or by any means electronic or mechanical, including photocopying, recording, microcopying, or by any information storage and retrieval system, without permission in writing from the publisher.

CC Copyright 2001 by S. Karger AG, P.O. Box, CH-4009 Basel (Switzerland)

Printed in Switzerland on acid-free paper by Reinhardt Druck, Basel

ISSN $0254-5020$

ISBN 3-8055-7131-3 


\section{Contents}

VII Preface

1 An Evaluation of the Methodology for the Assessment of Body Composition in Children and Adolescents

Hills, A.P.; Lyell, L.; Byrne, N.M. (Brisbane)

14 Comparison of Arm-to-Leg and Leg-to-Leg (Standing) Bioelectrical Impedance Analysis for the Estimation of Body Composition in 8- to 10-Year-Old Children

Rowlands, A.V.; Eston, R.G. (Bangor)

25 Measurement of Total Body Protein in Childhood Baur, L.A.; Allen, J.R.; Humphries, I.R.; Gaskin, K.J. (Sydney)

36 The Relationship of Subcutaneous Adipose Tissue Topography (SAT-Top) by Means of LIPOMETER with Body Mass Index and Body Composition in Obese Children and Adolescents Sudi, K.; Möller, R.; Tafeit, E.; Weinhandl, G.; Borkenstein, M.H. (Graz)

46 Prediction Equations for the Determination of Body Composition in Children Using Bioimpedance Analysis Bunc, V. (Prague)

53 Whole Body Resistance Measured between Different Limbs and Resistance Indices in Pre-Adolescent Children Jürimäe, J.; Leppik, A.; Jürimäe, T. (Tartu)

61 Influence of Anthropometric Variables to the Whole-Body Resistance in Pre-Adolescent Children

Jürimåe, T.; Leppik, A.; Jürimåe, J. (Tartu) 
71 Relationships between Anthropometric Parameters and Sexual Maturation in 12- to 15-Year-Old Estonian Girls

Veldre, G.; Jürimäe, T.; Kaarma, H. (Tartu)

85 A Century of Growth in Australian Children

Olds, T.; Dollman, J.; Norton, K.; Harten, N. (Underdale)

104 Body Image and Its Relationship with Body Composition and Somatotype in Adolescents

Viviani, F. (Padua)

115 Gender and Activity Comparison of Body Composition among Australian Children

Ackland, T.R.; Blanksby, B.A. (Nedlands)

132 Explaining Cardiovascular Disease Risk Factor Variability in Obese Teenagers Using Measured and Predicted Values of Visceral Adipose Tissue

Owens, S.; Litaker, M.; Gutin, B. (Augusta)

139 The Use of Different Prediction Equations for the Assessment of Body Composition in Young Female Gymnasts - Is There a Best Equation? Claessens, A.L.; Delbroek, W.; Lefevre, J. (Leuven)

155 Longitudinal Relationship between the Development of Body Fat Mass in Adolescent Males and Females and Their Eating and Activity Pattern Kemper, H.C.G.; van Mechelen, W.; Post, G.B; Twisk, J.W.R.; de Vente, W. (Amsterdam)

168 Validation of Foot to Foot Bioelectrical Impedance in 6- to 10-YearOld Children

Abott, R.A.; Davies, P.S.W. (Brisbane)

175 Conclusions and Perspectives

Jürimäe, T. (Tartu) ; Hills, A.P. (Brisbane)

177 Author Index

178 Subject Index 


\section{........................... \\ Preface}

This book has been published because we considered it necessary to present, in a simple publication, details of the methods used in the study of body composition in children with specific examples of the results obtained using some of these approaches. To date, descriptions of methods have often been incomplete in the literature. The following 15 chapters present a range of different aspects of this unique topic ranging from simple anthropometry to the technologically advanced technique of magnetic resonance imaging. This monograph represents what should be considered as the beginning as there is strong evidence to suggest that there is a need to conduct further research on this topic in the future.

Several excellent monographs with an emphasis on body composition assessment have been published in recent years. For example Roche AF, Heymsfield SB, Lohman TG: Human Body Composition. Human Kinetics, Champaign 1996, and Heyward VH, Stolarczyk LM: Applied Body Composition Assessment. Human Kinetics, Champaign 1996. American Journal of Human Biology [vol 11/2, 1999] published a special issue concerning body composition. Systematically, international symposia on in vivo body composition studies have been organised, the most recent of which was in Brookhaven National Laboratory, Upton, N.Y., USA in October 1999. However, monographs with a singular focus on the body composition problems in children have been lacking.

Traditional simple approaches in body composition assessment include the use of body stature and body mass as indices of obesity and using the two-component system of estimating fat and lean body mass for describing body composition changes associated with children's growth and development. 
The development of better approaches to body composition assessment will lead to an improved understanding of growth and development and the effects of exercise and dietary restriction on body composition. In addition, further research may help provide sound criteria for the validation of new methods of assessment.

Most of the work in the field is descriptive with an emphasis on the effects of growth and maturation and on comparisons of responses to different interventions (for example, diet and exercise) among children, adolescents and adults. Few studies explore the mechanisms of such differences. One of the main reasons for the relatively slow evolution in the knowledge and understanding of child-related issues is ethics. There is little justification, for example, in the use of risky (radioactive markers), painful or potentially extremely uncomfortable procedures (such as hydrostatic weighing), unless these are indicated clinically. There will always be a place for valid and reliable methods which are safe, quick, comfortable and cheap to use with pediatric populations.

In summary, this volume provides details of some new approaches and methods for the measurement of growth and body composition in children and youth of particular relevance to epidemiologists, pediatricians, teachers, coaches and sport specialists.

The editors wish to express their thanks to all of the contributing authors for their support and enthusiasm in the preparation of manuscripts.

Toivo Jürimäe, Tartu Andrew P. Hills, Brisbane 